\section{穴 Heighten Science \\ P U B L I C I T I O N S Corporation}

ISSN

2573-7716

\title{
Facial Paralysıs During Varicella Zoster Infection in a child
}

\author{
Fatih Oghan*, Muhammet Fatih Topuz and Onur Erdogan \\ Department of Otorhinolaryngology, Dumlupinar University, Medical Faculty, Kutahya, Turkey
}

*Address for Correspondence: Dr.Fatih Oghan, M.D, Associate Professor, Department of Otolaryngology, Medicine Faculty of Dumlupinar University, Kütahya, Turkey, Tel: +905057267375, Fax:+902742316673; Email: fatihoghan@ hotmail.com

Submitted: 06 March 2017

Approved: 21 March2017

Published: 23 March 2017

Copyright: @ 2017 Oghan F, et al. This is an open access article distributed under the Creative Commons Attribution License, which permits unrestricted use, distribution, and reproduction in any medium, provided the original work is properly cited.

Keywords: Varicella; Facial palsy

\section{ABSTRACT}

Introduction: Primary infection with varicella-zoster virus (VZV) results in chickenpox, characterized by viremia with a diffuse rash and seeding of multiple sensory ganglia, where the virus establishes lifelong latency. Herpes zoster is caused by reactivation of latent VZV in cranial-nerve or dorsal-root ganglia, with spread of the virus along the sensory nerve to the dermatome. Both entities have a benign clinical course in immunocompetent and young individuals. Although Herpes zoster virüs may result in Ramsey Hunt sendrom, it may rarely cause peripheral facial paralysis in the course of varicella

Case: A 4-year-old girl patient was admitted to the ear, nose, and throat clinic with a complaint of a rash over the body with vesicles and pustules a few days. She had left peripheral facial palsy about 2 days ago. In a general clinical examination, a few macular lesions, probably residues of vesicles, and fluid-filled blisters and pustules were observed on the back, chest, abdomen, upper, and lower limbs. She had remarkable left peripheral facial palsy. Her facial palsy was assessed as a grade II using the House-Brackmann Score. Otoscopic examination was normal and otalgia and auricular vesicle was absent. $1 \mathrm{mg} / \mathrm{kg} /$ day prednisone and $30 \mathrm{mg} / \mathrm{kg} /$ day acyclovir therapy were given to the patient due to the peripheral facial nerve palsy involvement of the VZV infection. Complete remission was achieved at 1 month after treatment.

Conclusion: Varicella-zoster virus (VZV) is one of eight herpes viruses known to cause human infection and is distributed worldwide. While the results of bell palsy are good, facial paralysis results during viral infections are severe. Cranial nerve involvement secondary to viral infection should be followed closely. The current standard of care for treatment is acyclovir and prednisone. Thus early treatment can be started in the face of developing complications and possible mortality and morbidity can be prevented.

\section{INTRODUCTION}

Varicella zoster virus (VZV) is a double-stranded IDNA virus from the herpes virus family. Primary infection with varicella-zoster virus (VZV) results in chickenpox, characterized by viremia with a diffuse rash and seeding of multiple sensory ganglia, where the virus establishes lifelong latency. Herpes zoster is caused by reactivation of latent VZV in cranial-nerve or dorsal-root ganglia, with spread of the virus along the sensory nerve to the dermatome [1]. Chickenpox is usually a self-limiting disease but it rarely causes complications. Although these complications may be due to secondary bacterial complications, VZV rarely may occur in severe neurological complications[2-4]. As a rare condition, peripheral facial paralysis may be encountered during or after varicella[4]. For this comorbid condition, the current standard of care for treatment is acyclovir and prednisone [5]. The purpose of this article is report a case related a girl with peripheral facial palsy during the course of varicella infection.

\section{CASE}

A 4-year-old girl patient was admitted to the ear, nose, and throat clinic with a complaint of a rash over the body with vesicles and pustules a few days. It was learned from her medical history that she had left peripheral facial palsy about 2 days ago. No relevant drug, dental, and family history was recorded. 
In a general clinical examination, a few macular lesions, probably residues of vesicles, and fluid-filled blisters and püstüles were observed on the back, chest, abdomen, upper, and lower limbs figure 1. She had remarkable left peripheral facial palsy. Her facial palsy was assessed as a grade II using the House-Brackmann Score and other cranial nerve (CN) examinations were normal figure 2. Otoscopic examination was normal and otalgia and auricular vesicle was absent. Clinical signs of icterus, pallor, clubbing, edema, cyanosis, and lymphadenopathy were absent. On evaluation of vital signs, temperature was noted to be $37.2^{\circ} \mathrm{C}$ and blood pressure $110 / 70 \mathrm{~mm}$ of $\mathrm{Hg}$. The laboratory examination of the blood serum showed that Complete blood count, routine biochemical and serological investigations were within normal limits.

Correlating the case history and clinical findings, a final diagnosis of peripheral facial paralysis with varicella zoster infection was given. Lumbar puncture and cerebrospinal fluid analysis could not be performed because of the patient's parents did not want to do it. $1 \mathrm{mg} / \mathrm{kg} /$ day prednisone and $30 \mathrm{mg} / \mathrm{kg} /$ day acyclovir therapy were given to the patient due to the peripheral facial nerve palsy involvement of the VZV infection. After a partial clinical recovery, she was discharged with suggestions. On examination of the patient after 1 month, regression of a number of lesions were noted with the formation of scar tissue and hypopigmented areas and complete remisson of fasial weakness No fresh vesicles were reported.

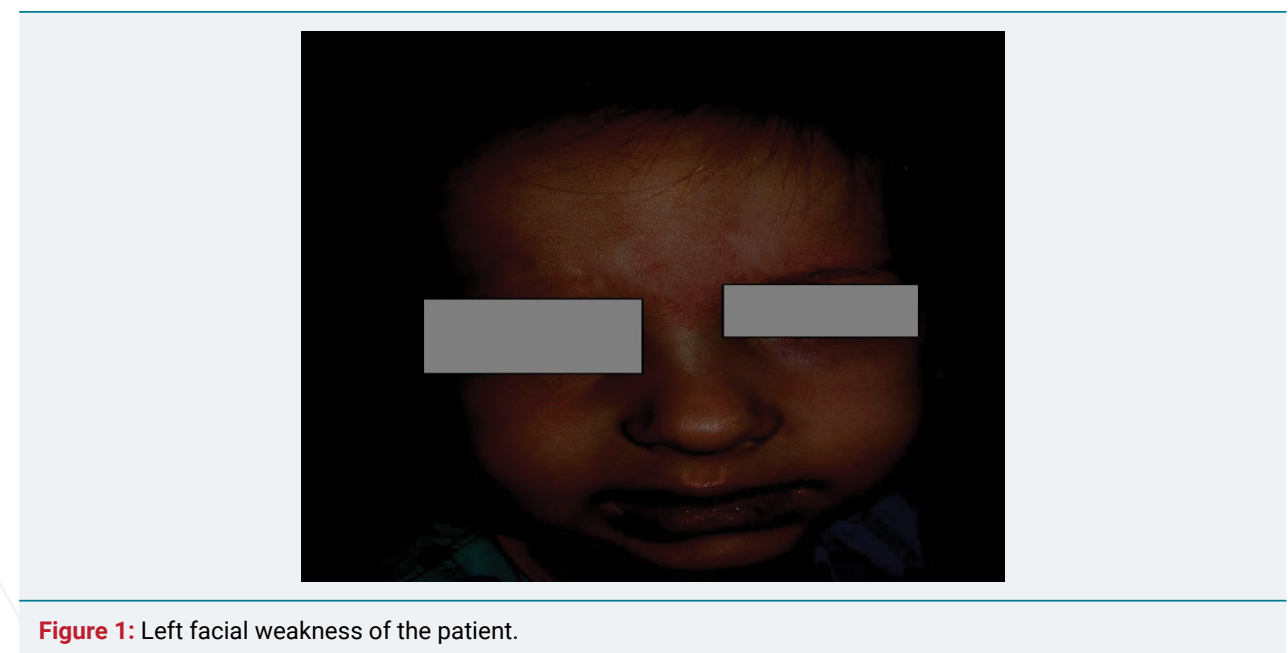

Figure 1: Left facial weakness of the patient.

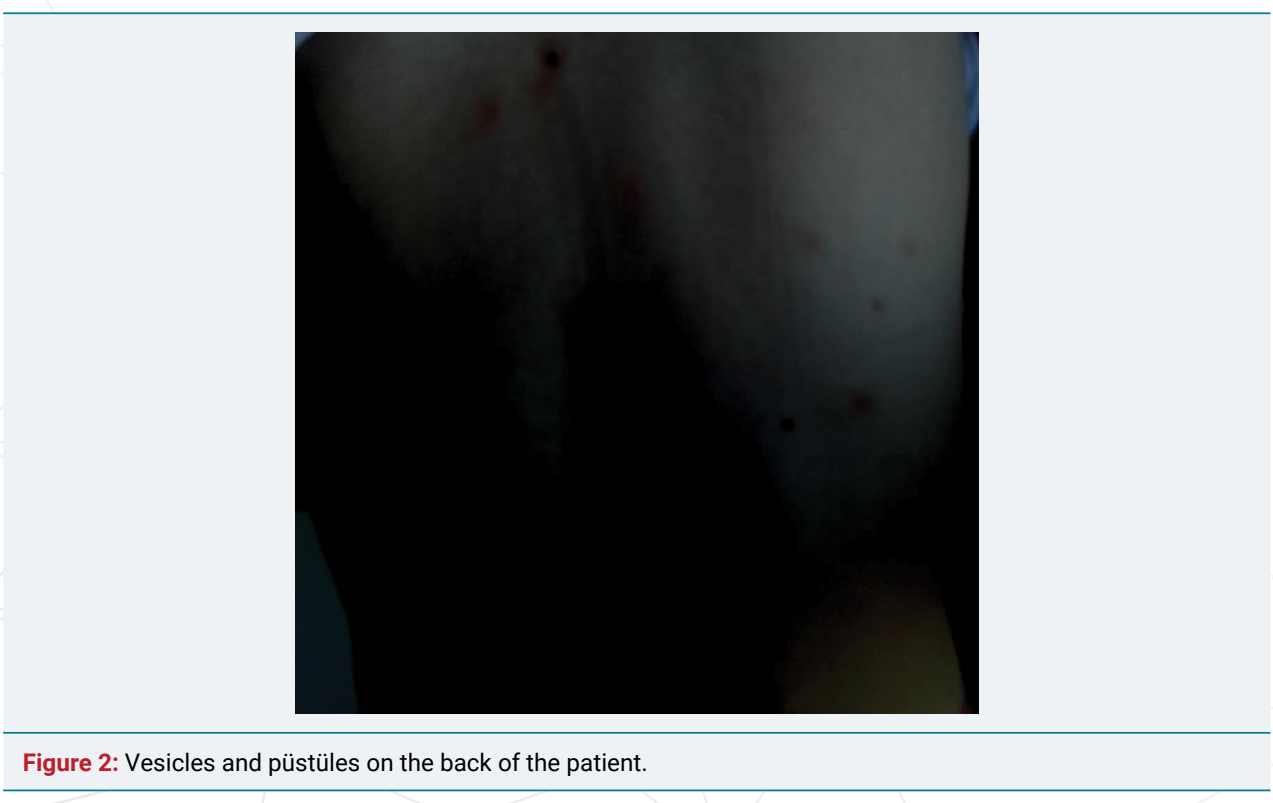




\section{DISCUSSION}

Chickenpox is a common disease in childhood characterized by infectious, feverish, and rashes [2]. It is a self-limiting and usually lasting 7-10 days. The occurrence of complications may be due to immunity, chronic diseases and age-related [6]. Complications are seen in adults rather than children [7]. The most common complication is secondary bacterial skin infections.

The incidence of neurological complications is reported as $0.03 \%$ [3-5]. Neurological complications in a wide range extend from encephalitis to cerebellar ataxia. Encephalitis, acute cerebellar ataxia, myelitis and meningitis are the most common neurological complications [8]. More rare are Guillain-Barr'e syndrome, meningoencephalitis, optic neuritis, contralateral hemiparalysis, peripheral motor neuropathy, cerebral anjitis, and Reye's syndrome [3-6,9]. Although lower cranial nerve (CN) palsies are less frequent, many patient reports observed the facial (VII), glossopharyngeal (IX) and vagus nerve (X) palsy of patients caused by VZV infection [10]. Also, there are publications mentioning the involvement of the trigeminal nerve (V), the spinal accessory nerve (XI), and the hypoglossal nerve (XII) in the literatüre [11]. There were no complications other than facial paralysis in our cases. Peripheral facial paralysis can occur before, during, or after rashes [12]. In literature; it is reported that facial paralysis is expected to be bilateral but rarely it may also be unilateral $[4,5,12,13]$. We present a case of unilateral peripheral facial paralysis that occurred in the presence of rash.

The etiopathogenesis of facial paralysis has not been clearly explained. However. two mechanisms are considered [12]. The first is that virus toxins directly affect the facial nerve, and the second is that antibodies against viruses may have damaged the facial nerve [13]. As a matter of fact, in our case, when the disease recovers during the healing period, it coincides with the theory of the formation of facial paralysis under the influence of antibodies.

The diagnosis of VZV with peripheral facial palsy is generally made based on clinical findings, In the early stages of the disease, it can be difficult to distinguish from the more common Bell's palsy; however, if the patient presents with rashes over the body with vesicles and pustules, and CN VII nerve palsy, treatment for VZV should be considered as early intervention has been show to improve long term outcomes of facial paralysis. Because of the no consensus in the treatment of neurological complications, treatment is applied according to the clinic of each patient. In general, acyclovir and/or steroids are preferred for treatment $[4,12,13]$. We were hospitalized in terms of comorbid conditions in which our patient may develop. $1 \mathrm{mg} / \mathrm{kg} /$ day prednisone with tapering dose and antiviral drug therapy was started with $30 \mathrm{mg} / \mathrm{kg} /$ day acyclovir for 5 days. The patient was discharged home on hospital day 5 with two weeks of valacyclovir and an oral prednisone taper with close follow up. Complete remission was achieved at 1 month after treatment.

\section{CONCLUSION}

Varicella-zoster virus (VZV) is one of eight herpesviruses known to cause human infection and is distributed worldwide While the results of bell palsy are good, facial paralysis results during viral infections are severe. Cranial nerve involvement secondary to viral infection should be followed closely. The current standard of care for treatment is acyclovir and prednisone Thus early treatment can be started in the face of developing complications and possible mortality and morbidity can be prevented. 


\section{REFERENCES}

1. Yalaki Z, Öztürk A, Taşar MA, Dallar Y. Herpes Zoster Infections In Healthy Children. Cocuk Enf Derg. 2010; 4: 96-99. Ref.: https://goo.gl/HICORs

2. Gershon AA. Varicella-zoster virus infections. Pediatr Rev. 2008; 29: 5-10. Ref.: https://goo.gl/nPFK3I

3. Gnann JW Jr. Varicella-zoster virus: a typical presentations and unusual complications. J Infect Dis. 2002; 186: 91-98. Ref.: https://goo.gl/g0vcty

4. Yilmaz C, Aksen HC. Severe neurological complications of chickenpox: Report of four cases. Eur J Gen Med. 2005; 2: 177-179. Ref.: https://goo.gl/deYDD5

5. Rama Rao G, Amareswar A, Kishan Kumar Y, Rani R. Isolated facial palsy in varicella. Indian J Dermatol Venereol Leprol. 2008; 74; 261-262. Ref.: https://goo.gl/esIOVI

6. Bozzola E, Tozzi AE, Bozzola M, Krzysztofiak A, Valentini D, et al. Neurological complications of varicella in childhood: case series and a systematic review of the literature. Vaccine. 2012; 30:57855790. Ref.: https://goo.gl/UxYlfV

7. Danovaro-Holliday MC, Gordon EJ, Jumaan AO, Woernle C, Judy RH, et al. High rate of varicella complications among Mexican-born adults in Alabama. Clin Infect Dis. 2004; 39: 1633-1639. Ref.: https://goo.gl/xRUjo5

8. Amlie-Lefond C, Jubelt B. Neurologic manifestations of varicella zoster virus infections. Curr Neurol Neurosci Rep. 2009; 9: 430-434. Ref.: https://goo.gl/HbCusd

9. Riaza G'omez M, De la Torre Espi M, Bartolome SM, Molina Cabanero JC, Tamariz-Martel Moreno A. [Complications of varicella in children]. An Esp Pediatr. 1999; 50: 259-262. Ref.: https://goo.gl/o48gQs

10. Iwasaki H, Toda N, Takahashi M, Azuma T, Nakamura $\mathrm{K}$, et al. Vestibular and cochlear neuritis in patients with Ramsay Hunt syndrome: a Gd-enhanced MRI study. Acta Otolaryngol. 2013; 133: 373377. Ref.: https://goo.gl/gmTs90

11. Gunbey HP, Kutlar G, Aslan K, Sayit AT, Incesu L. Magnetic Resonance Imaging Evidence of Varicella Zoster Virus Polyneuropathy: Involvement of the Glossopharyngeal and Vagus Nerves Associated With Ramsay Hunt Syndrome. Journal of Craniofacial Surgery. 2016; 27: 721-723. Ref.: https://goo.gl/CnoEzp

12. Odemis E, Turkay S, Tunca A, Karadag A. Acute peripheral facial palsy during chickenpox in a child. J Pediatr Neurol. 2004; 2: 245-246. Ref.: https://goo.gl/w1UrVb

13. Muñoz-Sellart M, García-Vidal C, Martínez-Yelamos S, Niubó J, Fernández-Viladrich P. Peripheral facial palsy after varicella. Report of two cases and review of the literature. Enferm Infecc Microbiol Clin. 2010; 28: 504-508. Ref.: https://goo.gl/RxmHaJ 